\title{
Synthesis and crystal structure of [chlorobis(triphenylphospino) (p-chlorobenzaldehyde thiosemicarbazone)] copper(I) complex
}

\author{
ASHIQ KHAN ${ }^{\mathrm{a}}$, POONAM SHARMA ${ }^{\mathrm{a}}$, RAJNIKANT ${ }^{\mathrm{b}}$, VIVEK K GUPTA ${ }^{\mathrm{b}}$, NARESH PADHA ${ }^{\mathrm{b}}$ \\ and REKHA SHARMA ${ }^{\mathrm{a}, *}$ \\ a Department of Chemistry, Lovely Professional University, Phagwara, Punjab, India \\ ${ }^{b}$ Post Graduate Department of Physics \& Electronics, University of Jammu, Jammu Tawi 180006, India \\ e-mail: rekha.14537@1pu.co.in
}

MS received 9 June 2015; revised 13 December 2015; accepted 14 December 2015

\begin{abstract}
Reactions of copper(I) halides with p-chlorobenzaldehyde thiosemicarbazone $\left(\mathrm{H}^{1} \mathrm{~L}\right)$ and triphenylphosphine in $1: 1: 2$ molar ratio yielded complexes of stoichiometry, $\left[\mathrm{CuX}\left(\eta^{1}-\mathrm{S}-\mathrm{H}^{1} \mathrm{~L}\right)\left(\mathrm{Ph}_{3} \mathrm{P}\right)_{2}\right](\mathrm{X}=\mathrm{I}$, 1: $\mathrm{Br}, 2 ; \mathrm{Cl}, 3$ ). All the three complexes were characterized using analytical (CHNS) and spectroscopic (IR, ${ }^{1} \mathrm{H}$ NMR) techniques. The structure of complex $\mathbf{3}$ was confirmed by X-ray crystallography. It has been found to crystallize in the triclinic system with space group P-1 and unit cell parameters: $a=10.207(5) \AA, b=$ 13.027(5) $\AA, \mathrm{c}=16.269(5) \AA, \alpha=100.054(5)^{\circ}, \beta=99.228(5)^{\circ}$ and $\gamma=97.234(5)^{\circ}$. This complex has distorted tetrahedral geometry with two phosphorus atoms from two triphenylphosphine ligands, thione sulfur of thiosemicarbazone ligand and chloride ion occupying the four corners of the tetrahedron. The structure of complex 3 was in contrast to sulfur-bridged dinuclear complex of copper(I) chloride with benzaldehydethiosemicarbazone, $\left[\mathrm{Cu}_{2} \mathrm{Cl}_{2}\left(\mu_{2} \text {-S-Hbtsc }\right)_{2}\left(\mathrm{Ph}_{3} \mathrm{P}\right)_{2}\right] \cdot 2 \mathrm{H}_{2} \mathrm{O}$. The intermolecular H-bonding, $\mathrm{Cl} \cdots \mathrm{HC}_{\mathrm{ph}}, 2.733 \AA$ and $\pi$ interactions, $\left\{\mathrm{CH}_{\mathrm{ph}} \cdots \pi, 2.796 ; 2.776 \AA\right.$ in this complex led to the formation of 1D chain. Two such 1D chains were cross-linked via, $\mathrm{Cl} \cdots \mathrm{HC}_{\mathrm{ph}}, 2.896 \AA$ H-bonding to form a 2D network.
\end{abstract}

Keywords. p-chlorobenzaldehyde thiosemicarbazone; tetrahedral monomer; copper(I) halides; X-ray crystallography; hydrogen bonding; triphenylphosphine.

\section{Introduction}

Thiosemicarbazones $\left(\mathrm{R}^{1} \mathrm{R}^{2} \mathrm{C}^{2}=\mathrm{N}^{3}-\mathrm{N}^{2} \mathrm{H}-\mathrm{C}^{1}(=\mathrm{S}) \mathrm{N}^{1} \mathrm{HR}^{3}\right)$ are important $\mathrm{N}, \mathrm{S}$-donor ligands as they exhibit variable bonding modes, structural diversity, ${ }^{1-7}$ analytical applications ${ }^{8-13}$ and biological activities (antibacterial, antifungal, antitumor, antiamoebic, antimalarial, antiviral, radioprotective, trypanocidal and anti-inflammatory activities). ${ }^{14-18}$ Copper(I), being a soft acid, binds strongly with soft bases like sulfur, phosphorus and selenium. ${ }^{19-24}$ Coordination chemistry of copper(I) halides with thiosemicarbazones had proved to be very interesting as the substituents on $\mathrm{C}^{2}$ or $\mathrm{N}^{1}$ atoms of thiosemicarbazones, halogen atoms and solvent system played important role in generating complexes of variable geometries, nuclearities and bonding modes (Chart 1). ${ }^{24-32}$

When $\mathrm{C}^{2}$ carbon of thiosemicarbazone was substituted with pyridine, two phenyl rings or isatin ring at $\mathrm{C}^{2}$ carbon, only tetrahedral monomers of type A were obtained, ${ }^{19-25}$ whereas with thiophene, furan and pyrrole ring at $\mathrm{C}^{2}$ carbon, it formed only dimers, either

\footnotetext{
*For correspondence
}

of type $\mathrm{D}$ or $\mathrm{E}$ depending upon the halogen atom attached. ${ }^{19,28,29}$ Phenyl ring at $\mathrm{N}^{1}$ atom of thiosemicarbazone resulted into formation of either three coordinated monomer $(\mathrm{B})$ or sulfur bridged dimer $(\mathrm{F})$, where no triphenylphosphine molecule coordinated. ${ }^{28,29}$ Acetylthiophene-2-carbaldehyde thiosemicarbazone formed monomer with coordination number three of type $\mathrm{C}$ with copper(I) bromide and chloride. ${ }^{30}$ A unique type of hetero-bridging $(\mathrm{G})$ was observed in the complex of copper(I) iodide with acetophenone thiosemicarbazone. ${ }^{31}$ It was observed in literature that solvent also played an important role in altering the bonding modes. For example, benzaldehyde thiosemicarbazone formed tetrahedral monomer in acetonitrile, whereas a halogenbridged dimer was obtained from similar reaction in acetonitrile-chloroform mixture. ${ }^{32}$ Similar reaction with copper(I) bromide in acetonitrile formed bromobridged dimer, while the use of acetonitrile-chloroform mixture as solvent changed the bridging mode from halogen-bridging to sulfur bridging. ${ }^{32}$

In continuation to this work, in this paper, reaction of p-cholorobenzaldehye thiosemicarbazone $\left(\mathrm{H}^{1} \mathrm{~L}, \mathrm{I}\right)$ with copper(I) halides in the presence of triphenylphosphine as co-ligand has been investigated. The synthesized 
<smiles>[X]C(P)(P)P</smiles>

(A)

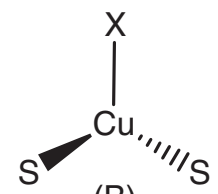

(B)

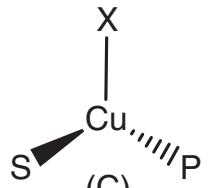

(C)

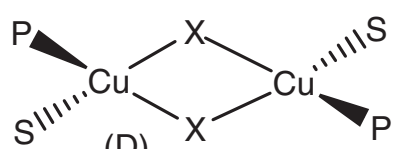

(D)

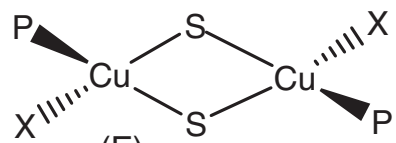

(E)

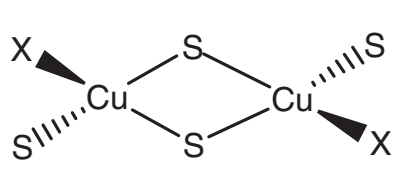

(F)

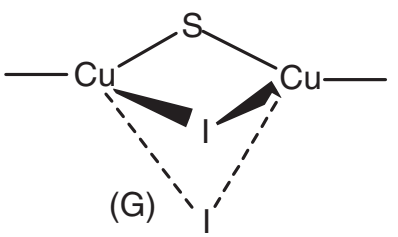

Chart 1. Types of bonding modes and nuclearity obtained for copper(I) halide complexes of thiosemicarbazones.

complexes were characterized using elemental analysis, IR, ${ }^{1} \mathrm{H}$ NMR and single crystal X-ray crystallography (complex 3).

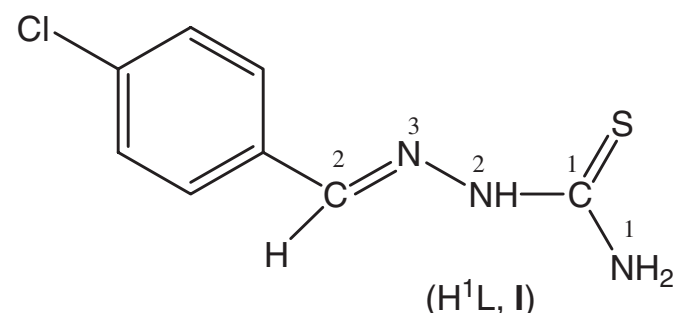

\section{Experimental}

\subsection{Synthesis}

2.1a $\quad\left[C u I\left(\eta^{1}-S-H^{1} L\right)\left(P h_{3} P_{2}\right)\right] 1$ : To a solution of $\mathrm{CuI}(0.050 \mathrm{~g}, 0.26 \mathrm{mmol})$ in $15 \mathrm{~mL}$ of acetonitrile was added solid $\mathrm{H}^{1} \mathrm{~L}(0.056 \mathrm{~g}, 0.26 \mathrm{mmol})$ and the reaction mixture was stirred for 3-4 h. To this was added solid $\mathrm{Ph}_{3} \mathrm{P}(0.137 \mathrm{~g}, 0.52 \mathrm{mmol})$ and stirred for $10-20$ min. The yellow coloured clear solution thus obtained was filtered and kept for crystallization at room temperature. Yield: $80 \%$; M.p. $190-192^{\circ} \mathrm{C}$. Elemental analysis for $\mathrm{C}_{44} \mathrm{H}_{38} \mathrm{~N}_{3} \mathrm{P}_{2} \mathrm{SClCuI}$, Found (\%): C, 56.87; H, 4.06; N, 4.51; S, 3.46. Calcd. (\%): C, 56.89; H, 4.09; $\mathrm{N}, 4.52 ; \mathrm{S}, 3.45$. Main IR peaks $\left(\mathrm{KBr}, \mathrm{cm}^{-1}\right), v(\mathrm{~N}-$ $\mathrm{H}), 3474 \mathrm{~s}, 3358 \mathrm{~m}, 3229 ; v(-\mathrm{NH}-), 3129 \mathrm{~m} ; v\left(\mathrm{C}-\mathrm{H}_{\mathrm{Ph}}\right)$, $3050 \mathrm{~s} ; \delta\left(\mathrm{NH}_{2}\right)+v(\mathrm{C}=\mathrm{N})+v(\mathrm{C}-\mathrm{C}), 1632 \mathrm{~s}, 1539 \mathrm{~s}$; $v(\mathrm{C}=\mathrm{S}) 829 \mathrm{~m}$ (thioamide moiety), $v\left(\mathrm{P}-\mathrm{C}_{\mathrm{Ph}}\right), 1094 \mathrm{~s} .{ }^{1} \mathrm{H}$ $\operatorname{NMR}\left(\mathrm{CDCl}_{3}, \delta \mathrm{ppm},\right): 10.23 \mathrm{~s}\left(1 \mathrm{H}, \mathrm{N}^{2} \mathrm{H}\right), 8.20 \mathrm{~s}(1 \mathrm{H}$, $\left.\mathrm{C}^{2} \mathrm{H}\right), 7.67-6.93 \mathrm{~m}\left(34 \mathrm{H}, \mathrm{C}^{4,5.7 .8} \mathrm{H}+\mathrm{Ph}_{3} \mathrm{P}\right)$.

Complexes $\mathbf{2}$ and $\mathbf{3}$ were prepared by similar method. 2.1b $\left[C u B r\left(\eta^{1}-S-H^{1} L\right)\left(P h_{3} P_{2}\right)\right] \quad 2:$ Yield: $75 \%$; M.p. $178-180^{\circ} \mathrm{C}$. Elemental analysis for $\mathrm{C}_{44} \mathrm{H}_{38} \mathrm{~N}_{3} \mathrm{P}_{2} \mathrm{SClCuBr}$, Found (\%): C, 59.91; H, 4.29; N, 4.74; S, 3.62. Calcd. (\%): C, 59.93; H, 4.31; N, 4.76; S, 3.63.Main IR peaks $\left(\mathrm{KBr}, \mathrm{cm}^{-1}\right), v(\mathrm{~N}-\mathrm{H})$, 3476s,3362s,3285m; $v(-\mathrm{NH}-), \quad 3134 \mathrm{~m} ; \quad v\left(\mathrm{C}-\mathrm{H}_{\mathrm{Ph}}\right)$, $3051 \mathrm{~s} ; \quad \delta\left(\mathrm{NH}_{2}\right)+v(\mathrm{C}=\mathrm{N})+v(\mathrm{C}-\mathrm{C}), 1582 \mathrm{~s}, 1541 \mathrm{~s} ;$ $v(\mathrm{C}=\mathrm{S}) 820 \mathrm{~m}$ (thioamide moiety), $v\left(\mathrm{P}-\mathrm{C}_{\mathrm{Ph}}\right), 1094 \mathrm{~s} .{ }^{1} \mathrm{H}$ NMR $\left(\mathrm{CDCl}_{3}, \delta \mathrm{ppm},\right): 10.41 \mathrm{~s}\left(1 \mathrm{H}, \mathrm{N}^{2} \mathrm{H}\right), 8.14 \mathrm{~s}(1 \mathrm{H}$, $\left.\mathrm{C}^{2} \mathrm{H}\right), 7.68-6.97 \mathrm{~m}\left(34 \mathrm{H}, \mathrm{C}^{4,5.7 .8} \mathrm{H}+\mathrm{Ph}_{3} \mathrm{P}\right)$.

2.1c $\quad\left[C u C l\left(\eta^{1}-S-H^{1} L\right)\left(P h_{3} P_{2}\right)\right] 3$ : Yield: 78\%; M.p. $181-183^{\circ} \mathrm{C}$. Elemental analysis for $\mathrm{C}_{44} \mathrm{H}_{38} \mathrm{~N}_{3} \mathrm{P}_{2}$ $\mathrm{SCl}_{2} \mathrm{Cu}$, Found (\%): C, 63.07; H, 4.52; N, 5.00; S, 3.84. Calcd. (\%): C, 63.04; H, 4.54; N, 5.01; S, 3.82.Main IR peaks $\left(\mathrm{KBr}, \mathrm{cm}^{-1}\right), v(\mathrm{~N}-\mathrm{H}), 3449 \mathrm{~s}, 3362 \mathrm{~s}, 3285 \mathrm{~m}$; $v(-\mathrm{NH}-), 3160 \mathrm{~m} ; v\left(\mathrm{C}-\mathrm{H}_{\mathrm{Ph}}\right), 3050 \mathrm{~s} ; \delta\left(\mathrm{NH}_{2}\right)+v(\mathrm{C}=\mathrm{N})$ $+v(\mathrm{C}-\mathrm{C}), 1591 \mathrm{~s}, 1545 \mathrm{~s} ; v(\mathrm{C}=\mathrm{S}) 818 \mathrm{~s}$ (thioamide moiety), $v\left(\mathrm{P}-\mathrm{C}_{\mathrm{Ph}}\right), 1092 \mathrm{~s} .{ }^{1} \mathrm{H} \mathrm{NMR}\left(\mathrm{CDCl}_{3}, \delta \mathrm{ppm},\right)$ : $10.35 \mathrm{~s}\left(1 \mathrm{H}, \mathrm{N}^{2} \mathrm{H}\right), 8.16 \mathrm{~s}\left(1 \mathrm{H}, \mathrm{C}^{2} \mathrm{H}\right), 7.65-6.98 \mathrm{~m}(34 \mathrm{H}$, $\left.\mathrm{C}^{4,5.7 .8} \mathrm{H}+\mathrm{Ph}_{3} \mathrm{P}\right)$.

\subsection{Chemicals and physical measurements}

Potassium chloride, potassium bromide, potassium iodide, triphenylphosphine, p-chloro-benzaldehyde, thiosemicarbazide and triphenylphosphine were procured from Loba Pvt. Ltd, Copper(I) iodide, bromide and chloride were prepared by the reduction of $\mathrm{CuSO}_{4}$. $5 \mathrm{H}_{2} \mathrm{O}$ using $\mathrm{SO}_{2}$ in the presence of $\mathrm{KI}, \mathrm{KBr}$ or $\mathrm{KCl}$ in water. $^{33}$ p-chlorobenzaldehydethiosemicarbazone was prepared by refluxing p-chlorobenzaldehyde and thiosemicarbazides in methanol for 4-5 h. C, H and $\mathrm{N}$ analyses were obtained with a Thermoelectron FLASHEA1112 CHNS analyzer. Infrared spectra were recorded from $\mathrm{KBr}$ pellets in the range $4000-200 \mathrm{~cm}^{-1}$ on a SHIMADZU FTIR 8400S spectrophotometer. Melting points were determined with an electrically heated Gallenkamp apparatus. ${ }^{1} \mathrm{H}$ NMR were recorded on an AV500 FT spectrometer operating at a frequency of $500 \mathrm{MHz}$ using $\mathrm{CDCl}_{3}$ as solvent with TMS as the internal standard. X-ray Diffraction(XRD) patterns of the powder were recorded on PANalytical X-ray powder diffractrometer (Model X'pert ${ }^{3}$ powder) with $\mathrm{CuK} \alpha$ radiation $(\lambda=1.5406 \AA$ ) with scan speed 0.066 degree per second in the $2 \theta$ range 5-40 for $1,5-80$ degrees for $\mathbf{2}$ and 5-50 degrees for $\mathbf{3}$.

\section{$2.3 X$-ray data collection, structure solution and refinement}

X-ray intensity data of 29686 reflections (of which 6397 unique) were collected on X'calibur CCD equipped 
Table 1. Crystallographic data of complex 3.

\begin{tabular}{|c|c|}
\hline Empirical Formula & $\mathrm{C}_{44} \mathrm{H}_{38} \mathrm{Cl}_{2} \mathrm{CuN}_{3} \mathrm{P}_{2} \mathrm{~S}$ \\
\hline Formula Weight & 837.21 \\
\hline Temperature (K) & 293(2) \\
\hline Wavelength $(\AA)$ & 0.71073 \\
\hline Crystal system & Triclinic \\
\hline Crystal size (mm) & $0.3 \times 0.2 \times 0.2$ \\
\hline Space group & $\mathrm{P}-1$ \\
\hline $\mathrm{Z}$, calculated & 2 \\
\hline Density $\left(\mathrm{g} \mathrm{cm}^{-3}\right)$ & 1.339 \\
\hline Absorption coefficient $\left(\mathrm{mm}^{-1}\right)$ & 0.817 \\
\hline $\mathrm{a}(\AA)$ & $10.207(5)$ \\
\hline $\mathrm{b}(\AA)$ & $13.027(5)$ \\
\hline$c(\AA)$ & $16.269(5)$ \\
\hline$\alpha\left(^{\circ}\right)$ & $100.054(5)$ \\
\hline$\beta\left(^{\circ}\right)$ & $99.228(5)$ \\
\hline$\gamma\left({ }^{\circ}\right)$ & $97.234(5)$ \\
\hline $\mathrm{V}\left(\mathrm{A}^{3}\right)$ & $2075.9(14)$ \\
\hline $\mathrm{F}(000)$ & 864 \\
\hline Theta range for data collection $\left(^{\circ}\right)$ & $3.48-26.00$ \\
\hline Limiting indices & $-12 \geq \mathrm{h} \geq 12,-16 \geq \mathrm{k} \geq 16,-20 \geq 1 \geq 20$ \\
\hline Reflections & 29686 \\
\hline Collected/unique & 8127 \\
\hline Completeness to theta & $3.48-26.00$ \\
\hline Data/restraints & $8127 / 0 / 423$ \\
\hline Goodness-of- fit on $F^{2}$ & 1.031 \\
\hline Final $R$ indices & $\mathrm{R} 1=0.0378 \mathrm{wR} 2=0.0866$ \\
\hline$[\mathrm{I}>2 \sigma(\mathrm{I})]$ & 6397 \\
\hline$R$ indices (all data) & $\mathrm{R} 1=0.0543 \mathrm{wR} 2=0.0969$ \\
\hline$\Delta \rho_{\max }, \Delta \rho_{\min }\left(\mathrm{e} \AA^{-3}\right)$ & $0.326,-0.343$ \\
\hline
\end{tabular}

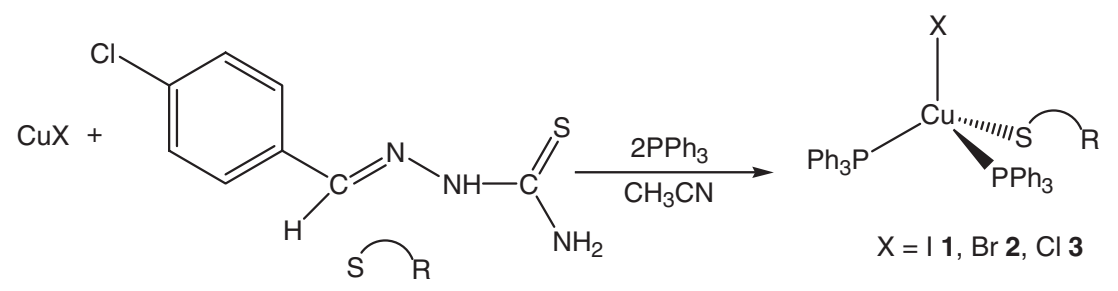

Scheme 1. Reaction scheme for synthesis of complexes 1-3.

Table 2. Selected bond length $(\AA)$ and bond angles $\left({ }^{\circ}\right)$ for complex 3 .

\begin{tabular}{lccc}
\hline Bond Lengths & & & \\
$\mathrm{Cu}(1)-\mathrm{S}(1)$ & $2.4534(9)$ & $\mathrm{S}(1)-\mathrm{C}(12)$ & $1.697(3)$ \\
$\mathrm{Cu}(1)-\mathrm{Cl}(1)$ & $2.3350(13)$ & $\mathrm{C}(12)-\mathrm{N}(7)$ & $1.320(3)$ \\
$\mathrm{Cu}(1)-\mathrm{P}(1)$ & $2.3024(10)$ & $\mathrm{C}(12)-\mathrm{N}(8)$ & $1.327(3)$ \\
$\mathrm{Cu}(1)-\mathrm{P}(2)$ & $2.2832(8)$ & & \\
& & & \\
Bond Angles & & & \\
$\mathrm{P}(1)-\mathrm{Cu}(1)-\mathrm{P}(1)$ & $123.54(3)$ & $\mathrm{Cl}(1)-\mathrm{Cu}(1)-\mathrm{S}(1)$ & $106.84(3)$ \\
$\mathrm{P}(2)-\mathrm{Cu}(1)-\mathrm{Cl}(1)$ & $110.93(3)$ & $\mathrm{N}(7)-\mathrm{C}(12)-\mathrm{N}(8)$ & $117.5(2)$ \\
$\mathrm{P}(1)-\mathrm{Cu}(1)-\mathrm{Cl}(1)$ & $102.32(3)$ & $\mathrm{S}(1)-\mathrm{C}(12)-\mathrm{N}(7)$ & $123.8(2)$ \\
$\mathrm{P}(2)-\mathrm{Cu}(1)-\mathrm{S}(1)$ & $102.50(3)$ & $\mathrm{Cu}(1)-\mathrm{S}(1)-\mathrm{C}(12)$ & $114.23(9)$ \\
$\mathrm{P}(1)-\mathrm{Cu}(1)-\mathrm{S}(1)$ & $109.90(3)$ & & \\
\end{tabular}




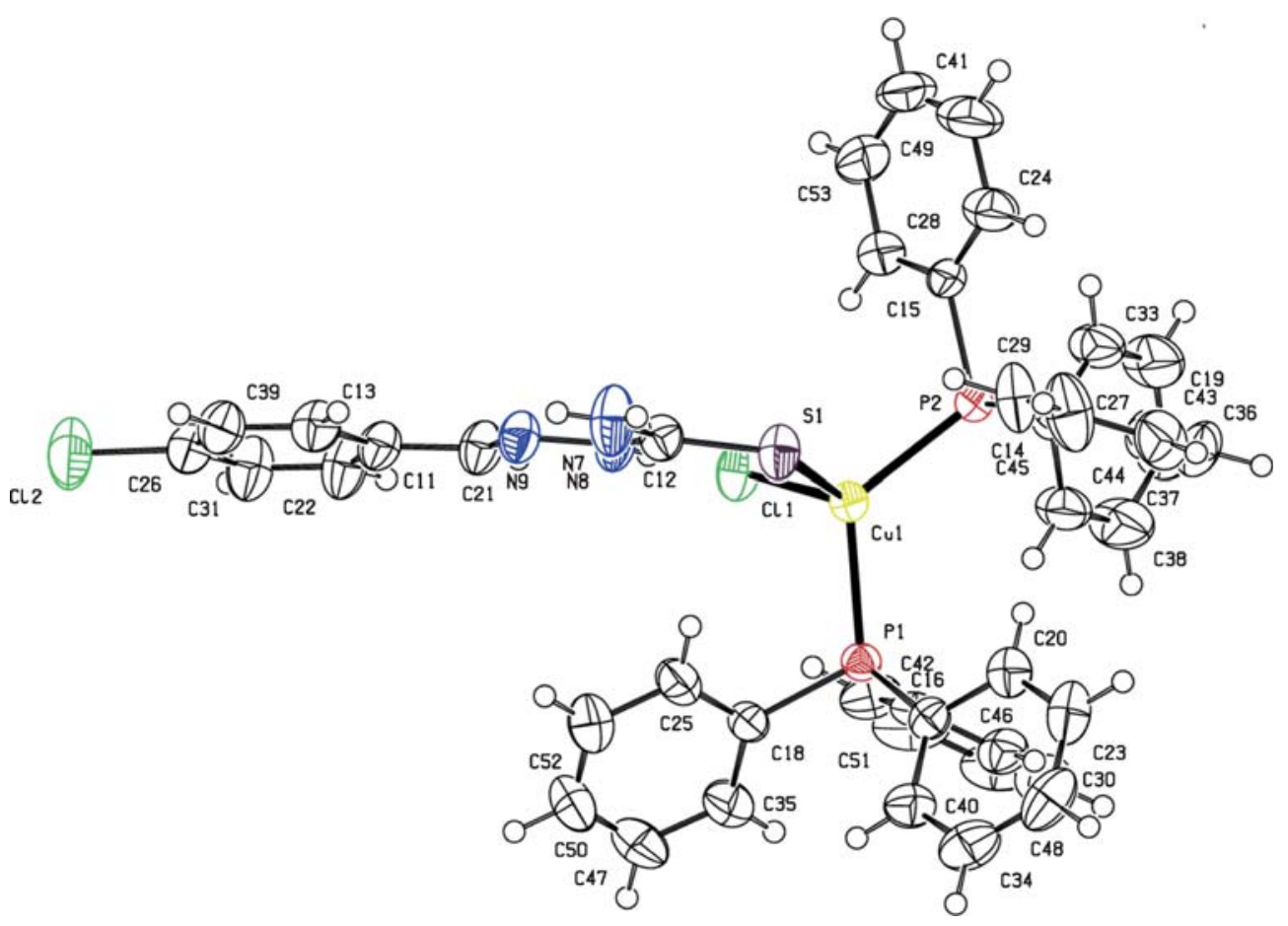

Figure 1. Molecular structure of complex 3 .

with graphite monochromated $\operatorname{MoK} \alpha$ radiation $(\lambda=$ $0.71073 \AA$ ). The crystal used for data collection was of dimensions $0.3 \times 0.2 \times 0.2 \mathrm{~mm}$. The cell dimensions were determined by least-squares fit of angular settings of 10580 reflections in the $\theta$ range 3.48 to $29.08^{\circ}$. The intensities were measured by $\omega$ scan mode for $\theta$ ranges 3.48 to $24.99^{\circ}$. 1798 reflections were treated as observed (I $>2 \sigma(\mathrm{I})$ ). Data were corrected for Lorentz, polarization and absorption factors. The structure was solved by direct methods using SHELXS97. ${ }^{34}$ All non-hydrogen atoms of the molecule were located in the best E-map. Full-matrix least-squares refinement was carried out using SHELXL97. ${ }^{35}$ The final refinement cycles converged to an $\mathrm{R}=0.0320$ and $\mathrm{wR}$ $\left(\mathrm{F}^{2}\right)=0.0835$ for the observed data. Residual electron densities ranged from -0.167 to $0.175 \mathrm{e}^{-3}$. The crystallographic data are summarized in table 1 .

\section{Results and Discussion}

Reaction of p-chlorobenzaldehydethiosemicarbazone $\left(\mathrm{H}^{1} \mathrm{~L}\right)$ with copper $(\mathrm{I})$ halides $(\mathrm{I}, \mathrm{Br}, \mathrm{Cl})$ and triphenylphosphine in $1: 1: 1\left(\mathrm{~L}: \mathrm{M}: \mathrm{PPh}_{3}\right)$ molar ratio formed insoluble compounds of stoichiometry, $\left\{\mathrm{CuX}\left(\mathrm{H}^{1} \mathrm{~L}\right)\left(\mathrm{Ph}_{3} \mathrm{P}\right)\right\}$. An effort was made to solubilize it, but no crystalline product was obtained. To solubilize these compounds, one extra mole of triphenylphosphine was added, which yielded complexes of stoichiometry, $\left[\mathrm{CuX}\left(\eta^{1}-\mathrm{S}-\mathrm{H}^{1} \mathrm{~L}\right)\left(\mathrm{Ph}_{3} \mathrm{P}\right)_{2}\right](\mathrm{X}=\mathrm{I}$
(1), $\mathrm{Br}$ (2), $\mathrm{Cl}$ (3) (scheme 1). Geometry around copper center was found to be distorted tetrahedral in complex 3. This monomer was in contrast to the previous results with benzaldehydethiosemicarbazone, where sulfur bridged dimer $\left[\mathrm{Cu}_{2}\left(\mu_{2}-\mathrm{S}\right.\right.$ Hbtsc $\left.)_{2}\left(\mathrm{Ph}_{3} \mathrm{P}\right)_{2} \mathrm{Cl}_{2}\right] \cdot 2 \mathrm{H}_{2} \mathrm{O}$ was formed with copper(I) chloride. ${ }^{19}$ It was already proved by theoretical studies that tetrahedral monomer and halogen-bridged dimers were thermodynamically more stable than S-bridged dimers. The S-bridged dimers could be stabilized by $\mathrm{H}-$ bonding between hydrogen atom of solvent molecule and halogen atom. ${ }^{19}$ Since there is no solvent molecule entrapped in the lattice of complex $\mathbf{3}$, formation of tetrahedral molecule is thermodynamically more favored. The CHN analysis of complexes 1-3 indicates that the molecular formula for all the three complexes are similar. The PXRD pattern. The peaks in PXRD pattern of

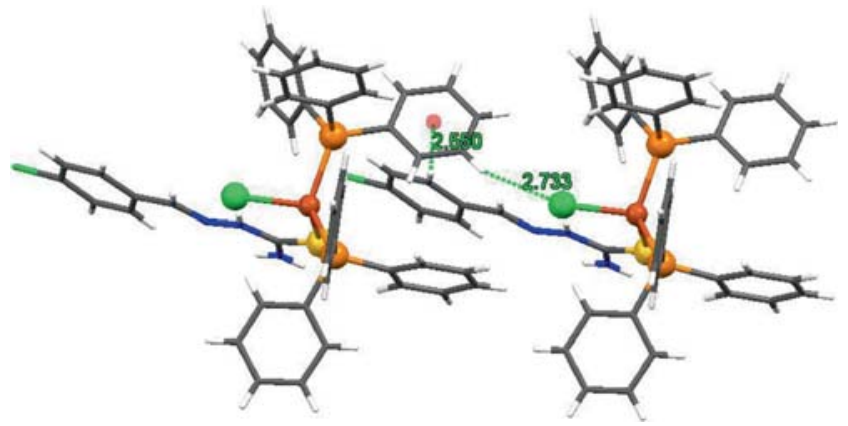

Figure 2. Interaction between two molecules of complex $\mathbf{3}$. 


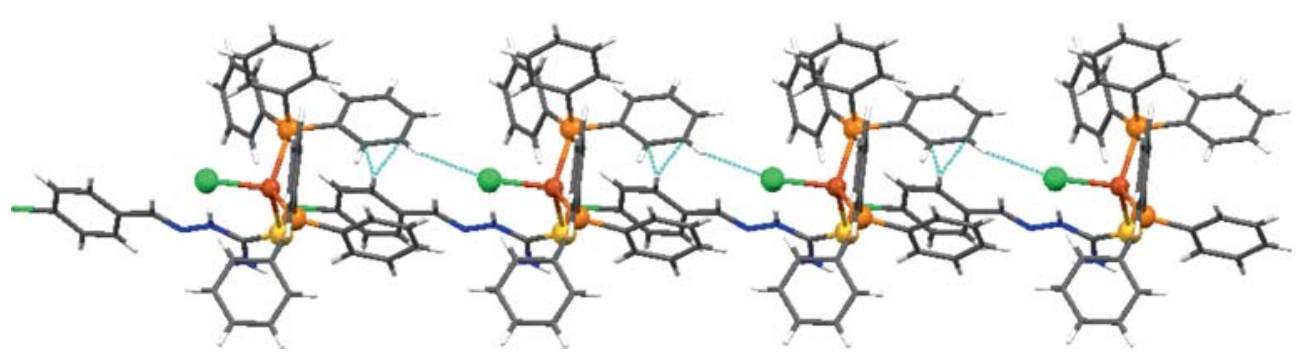

Figure 3. Intermolecular iteractions leading to the formation of $1 \mathrm{D}$ chain in $\mathbf{3}$.

these complexes appeared at different angles implying that the lattice structure of these complexes may be different due to the presence of different anions or solvent molecules (See Supplementary Information).

The $v(\mathrm{~N}-\mathrm{H})$ band due to $\left(-\mathrm{NH}_{2}\right)$ and $(-\mathrm{NH}-)$ groups appeared in ranges, 3476-3285 $\mathrm{cm}^{-1}$ and 3160-3129 $\mathrm{cm}^{-1}$, respectively. Presence of these bands suggested that thiosemicarbazone coordinated as neutral ligand in these complexes. Low energy shift of $v(\mathrm{C}=\mathrm{S})$ in complexes 1-3 (829 (1), 820 (2), 818(3) $\left.\mathrm{cm}^{-1}\right)$ vis-à-vis free ligand $\left(854 \mathrm{~cm}^{-1}\right)$ supported binding of ligand via thione sulfur. The appearance of characteristic $v\left(\mathrm{P}-\mathrm{C}_{\mathrm{Ph}}\right)$ in range 1092-1094 $\mathrm{cm}^{-1}$ in complexes 1-3 indicated coordination of $\mathrm{Ph}_{3} \mathrm{P}$ to metal center.

\subsection{Structure of complex 3}

The crystallographic data and important bond parameters (bond lengths and bond angles) of complex $\mathbf{3}$ are given in tables 1 and 2, respectively. The molecular structure along with numbering scheme is given in figure 1. Complex 3 crystallized in triclinic crystal system with space group P-1.

In complex $\mathbf{3}$, thione sulfur of p-chlorobenzaldehydethiosemicarbazone, chloride ion and two phosphorus atoms from two triphenylphosphine ligands occupied tetrahedral sites around the copper center. The $\mathrm{Cu}-\mathrm{S}$ bond length in complex 3, 2.4534(9) $\AA$ is close to the other copper(I) halide-thiosemicarbazone complexes reported in literature. ${ }^{19,20,25-27} \mathrm{The} \mathrm{Cu}-\mathrm{Cl}$ bond length, 2.3350(13) $\AA$ is less than the sum of ionic radii of $\mathrm{Cu}$ and $\mathrm{Cl}\left(\mathrm{Cu}^{+}, \mathrm{Cl}^{-}, 2.58 \AA\right){ }^{36}$ The $\mathrm{Cu}-\mathrm{P}$ bond lengths, $\{2.3024(10), 2.2832(8) \AA 3\}$ are close to literature value. ${ }^{19,20,25-27}$ The C-S bond length, 1.697(3) $\AA$ in 3 is close to free ligand $(1.687(3) \AA),{ }^{37}$ but much shorter than that, $\{1.772(4) \AA\}$ in $[\mathrm{PyPhHg}(\mathrm{btsc})]$ (btsc $=$ anionic form of benzaldehyde thiosemicarbazone), ${ }^{38}$ which indicates that ligand is coordinated to copper center in thione form. Two $\mathrm{S}-\mathrm{Cu}-\mathrm{P}$ bond angles are different, $\left\{\mathrm{S}-\mathrm{Cu}-\mathrm{P}(1), 109.90(3)^{\circ} ; \mathrm{S}-\mathrm{Cu}-\mathrm{P}(2)\right.$, $\left.102.50(3)^{\circ}\right\}$. The $\mathrm{S}-\mathrm{Cu}-\mathrm{Cl}$ and $\mathrm{P}-\mathrm{Cu}-\mathrm{P}$ bond angles are $106.84(3)^{\circ}$ and $123.54(3)^{\circ}$ respectively. The variation in these angles in 3 from $109.5^{\circ}$ reveals distortion from regular tetrahedral geometry. Coordination of two bulky triphenylphosphine molecules to copper, creates maximum distortion in $\mathrm{P}-\mathrm{Cu}-\mathrm{P}$ bond angle, $123.54^{\circ}$. The $\mathrm{Cu}-\mathrm{S}-\mathrm{C}$ bond angle, $114.23(9)^{\circ}$ is much larger than that in $[2-\mathrm{PyPhHg}(\mathrm{btsc})],\left\{99.09(12)^{\circ}\right\}$, where thiosemicarbazone ligand forms a chelate ring. ${ }^{38}$

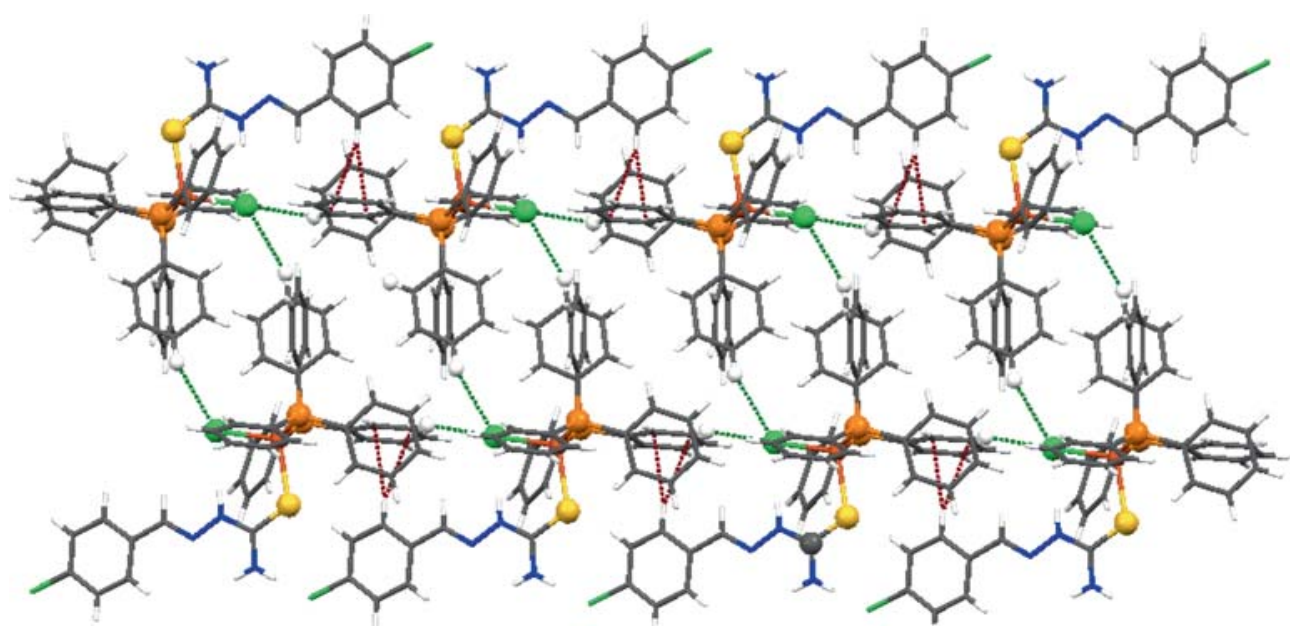

Figure 4. Inter molecular H-bonding within two 1D layer to form 2D layer isn complex 3 . 


\subsection{Supramolecular Architecture of complex 3}

Intermolecular H-bonding and different $\pi$-interactions in complex $\mathbf{3}$ has resulted in the formation of 2D sheet. The stepwise formation of supramolecular architecture of this complex can be explained as: two molecules of complex $\mathbf{3}$ are interconnected via H-bonding between chloride ion and phenyl hydrogen of triphenylphosphine, $\mathrm{Cl} \cdots \mathrm{HC}_{\mathrm{ph}}, 2.733 \AA$. These molecules also show strong $\pi$ interaction, $\left\{\mathrm{CH}_{\mathrm{ph}} \cdots \pi, 2.796 ; 2.776 \AA\right.$ to form dimeric unit. The distance between phenyl hydrogen of p-cholorobenzaldehyde ring and centroid of phenyl ring of triphenylphosphine is $2.550 \AA$ (figure 2). The same interactions are repeated to form 1D layer (figure 3).

Two such 1D layers are cross-linked by inter molecular H-bonding between metal bonded chloride ion of one layer and hydrogen phenyl ring of triphenylphosphine molecule of second ring, $\mathrm{Cl} \cdots \mathrm{HC}_{\mathrm{ph}}, 2.896 \AA$ and vice-versa to form a $2 \mathrm{D}$ sheet (figure 4 ).

\subsection{Solution phase behavior}

A broad singlet appeared in ${ }^{1} \mathrm{H}$ NMR spectra of complexes 1-3 in range $\delta 10.23-10.41 \mathrm{ppm}$ due to $\mathrm{N}^{2} \mathrm{H}$ proton. This signal shifted to low field vis-à-vis free ligand ( $\delta 9.32 \mathrm{ppm}$ ). The presence of $\mathrm{N}^{2} \mathrm{H}$ signal in complexes 1-3 ensured the coordination of thiosemicarbazones as neutral ligands. The $\mathrm{C}^{2} \mathrm{H}$ proton of thiosemicarbazone appeared at $\delta 8.20$ (1), 8.14 (2) and $8.16 \mathrm{ppm}(\mathbf{3})$. Other ring protons got obscured by the signals due to triphenylphosphine ring protons ( $\delta 7.65-6.93 \mathrm{ppm})$.

\section{Conclusions}

Reactions of copper(I) halides with p-chlorobenzaldehyde thiosemicarbazone and triphenylphosphine formed compounds of formula, [CuX $\left.\left(\eta^{1}-\mathrm{S}-\mathrm{H}^{1} \mathrm{~L}\right)\left(\mathrm{Ph}_{3} \mathrm{P}\right)_{2}\right](\mathrm{X}=$ $\mathrm{I}, \mathbf{1} ; \mathrm{Br}, \mathbf{2} ; \mathrm{Cl}, \mathbf{3})$. X-ray structure of complex $\mathbf{3}$ revealed a distorted tetrahedral geometry, in contrast to sulfurbridged dimer with benzaldehydethiosemicarbazone. ${ }^{19}$ Reason for change in nuclearity could be the absence of solvent in the lattice. The intermolecular H-bonding, $\mathrm{Cl} \cdots \mathrm{HC}_{\mathrm{ph}}, 2.733 \AA$ and $\pi$ interactions, $\left\{\mathrm{CH}_{\mathrm{ph}} \cdots \pi\right.$, $2.796 ; 2.776 \AA$ \} led to the formation of 1D chain. Two such 1D chains were cross-linked via H-bonding, $\mathrm{Cl} \cdots \mathrm{HC}_{\mathrm{ph}}, 2.896 \AA$ to form $2 \mathrm{D}$ network.

\section{Supplementary Information (SI)}

All details have been deposited with the Cambridge Crystallographic Data Centre, CCDC for $\mathbf{3}$ is 1042089.
Copies of this information can be obtained free of charge from The Director, CCDC, 12 Union Road, Cambridge CB2 1EZ, UK (fax: 44-1223-336-033; email: deposit@ccdc.cam.ac.uk; or http://www.ccdc. cam.ac.uk). Cif file of complex $\mathbf{3}$ and PXRD patterns of complexes 1-3 are given in Supplementary Information, available at www.ias.ac.in/chemsci.

\section{References}

1. Labana T S, Sharma R, Bawa G and Khanna S 2009 Coord. Chem. Rev. 253977

2. Padhye S B and Kauffman G 1985 Coord. Chem. Rev. 63127

3. West D X, Padhye S B and Sonawane P B 1991 Struct. Bonding (Berlin Ger) $\mathbf{7 6} 4$

4. West D X, Liberta A E, Padhye S B, Chikate R C, Sonawane P B, Kumbhar A S and Yerande R G 1993 Coord. Chem. Rev. 12349

5. Casas J S, Garcia-Tasende M S and Sordo J 2000 Coord. Chem. Rev. 209197

6. Smith D R 1997 Coord. Chem. Rev. 164575

7. Lobana T S, Khanna S, Sharma R, Hundal G, Sultana R, Chaudhary M, Butcher R J and Castineiras A 2008 Cryst. Growth Des. 81203

8. Mahajan R K, Kaur I and Lobana T S 2003 Talanta 59 101

9. Mahajan R K, Kaur I and Lobana T S 2006 Ind. J. Chem. 45A 639

10. Mahajan R K, Walia T P S, Sumanjit and Lobana T S 2005 Talanta 67755

11. Sarma L S, Kumar J R, Kumar C J and Reddy A V 2003 Anal. Lett. 36605

12. Reddy K J, Kumar J R, Ramachandraiah C, Thriveni T and Reddy A V 2007 Food Chem. 101585

13. Ali M A, Khalifa M E, Ghazy S E and Hassanien M M 2002 Anal. Sci. 181235

14. Abram U, Ortner K, Gust R and Sommer K $2000 \mathrm{~J}$. Chem. Soc., Dalton Trans. 735

15. Nomiya K, Sekino K, Ishiawa M, Honda A, Yokoyama M, Kasuga N C, Yokoyama H, Nakano S and Onodera K 2004 J. Inorg. Biochem. 98601

16. Ferrari M B, Bisceglie F, Pelosi G, Tarasconi P, Albertini R, Bonati A, Lunghi P and Pinelli S 2001 Inorg. Biochem. 83169

17. West D X, Ives J S, Krejci J, Salberg M M, Zumbahlen T L, Bain G A, Liberta A E, Valdes-Martinez J, Hernadez-Ortiz S and Toscano R A 1995 Polyhedron 14 2189

18. Garcia-Tojal J, Lezama L, Pizarro J L, Insausti M, Arriortua M I and Rojo T 1999 Polyhedron 183703

19. Lobana T S, Rekha, Butcher R J, Castineiras A, Bermejo E and Bharatam P V 2006 Inorg. Chem. 451535

20. Lobana T S, Sharma R, Castineiras A and Butcher R J 2010 Z. Anorg. Allg. Chem. 6362698

21. Venkateswaran R, Balakrishna M S, Mobin S M and Tuononen H M 2007 Inorg. Chem. 466335

22. Siddiqui M M, Mague J T and Balakrishna M S 2015 Inorg. Chem. $\mathbf{5 4} 6063$

23. Lobana T S, Rani A, Jassal A K and Jasinski J P 2015 J. Chem. Sci. 127149 
24. Lobana T S, Kaur A, Sharma R, Bala M, Jassal A K, Duff C E and Jasinski P J 2015 J. Chem. Sci. 127 1859

25. Lobana T S, Khanna S, Butcher R J, Hunetr A D and Zeller M 2006 Polyhedron 252755

26. Lobana T S, Rekha, Pannu A P S, Hundal G, Butcher R J and Castineiras A 2007 Polyhedron 26 2621

27. Lobana T S, Rekha, Castineiras A, Sandhu B S, Bermejo E and Nishioka T 2005 J. Coord. Chem. 58803

28. Lobana T S, Sharma R, Castineiras A, Hundal G and Butcher R J 2009 Inorg. Chim. Acta 3623547

29. Lobana T S, Sharma R, Hundal G, Castineiras A and Butcher R J 2012 Polyhedron 47134

30. Lobana T S, Kumari P, Sharma R, Castineiras A, Butcher R J, Akitsu T and Aritake Y 2011 Dalton Trans. 403219
31. Lobana T S, Khanna S, Butcher R J, Hunter A D and Zeller M 2007 Inorg. Chem. 465826

32. Lobana T S, Khanna S, Hundal G, Butcher R J and Castineiras A 2009 Polyhedron 283899

33. Brauer G 1965 In Handbook of Preparative Chemistry, Second ed. (New York: Academic Press) vol. 2

34. Sheldrick G M 1990 Acta Crystallogr. Sect. A 46467

35. Sheldrick G M, SHELXL-97 1997P In Program for the Refinement of Crystal Structures (University of Goettingen: Goettingen, Germany)

36. Huheey J E, Keiter E A and Keiter R L 1993 In Inorganic Chemistry: Principals of Structure and Reactivity, 4th ed (New York: Harper Collins)

37. Sampath N, Mathews R and Ponnuswamy M N $2010 \mathrm{~J}$. Chem. Crystallogr. $\mathbf{4 0} 1110$

38. Lobana T S, Rekha Butcher R J, Failes T W and Turner P 2005 J. Coord. Chem. 581369 